\title{
Depression, osteoporosis, serotonin and cell membrane viscosity between biology and philosophical anthropology
}

\author{
Massimo Cocchi ${ }^{1,2^{*}}$, Lucio Tonello ${ }^{1}$, Fabio Gabrielli ${ }^{1}$ and Massimo Pregnolato ${ }^{1,3}$
}

\begin{abstract}
Due to the relationship between biology and culture, we believe that depression, understood as a cultural and existential phenomenon, has clear markers in molecular biology. We begin from an existential analysis of depression constituting the human condition and then shift to analysis of biological data confirming, according to our judgment, its original (ontological) structure. In this way philosophy is involved at the anthropological level, in as much as it detects the underlying meanings of depression in the original biological-cultural horizon of human life. Considering the integration of knowledge it is the task of molecular biology to identify the aforementioned markers, to which the existential aspects of depression are linked to. In particular, recent works show the existence of a link between serotonin and osteoporosis as a result of a modified expression of the low-density lipoprotein receptor-related protein 5 gene. Moreover, it is believed that the hereditary or acquired involvement of tryptophan hydroxylase 2 (Tph2) or 5-hydroxytryptamine transporter $(5-\mathrm{HTT})$ is responsible for the reduced concentration of serotonin in the central nervous system, causing depression and affective disorders. This work studies the depression-osteoporosis relationship, with the aim of focusing on depressive disorders that concern the quantitative dynamic of platelet membrane viscosity and interactome cytoskeleton modifications (in particular Tubulin and Gsa protein) as a possible condition of the involvement of the serotonin axis (gut, brain and platelet), not only in depression but also in connection with osteoporosis.
\end{abstract}

\section{Depression and existential analysis}

Memory is not a place of filing and storage of data geographically placed in our brain, because the brain is not merely a 'bundle of neurons' vivisected in a laboratory. It is in fact the 'condition of possibility' of an integral being, of an organism having continuously interacting levels: from the most elementary conatus sese conservandi to the feeling of life [1].

The conscience, as individual expression, full of phenomena and meaning, originating from its biological roots, considers memory as the most authentic figure of life and death, or rather the original picture of tragedy that has always lived in us.

'Consider the cattle, grazing as they pass you by. They do not know what is meant by yesterday or today, they

\footnotetext{
* Correspondence: massimo.cocchi@unibo.it

'Institute 'Paolo Sotgiu' Quantitative and Evolutionary Psychiatry and Cardiology, L.U.De.S. University, Lugano, Switzerland, Via dei Faggi. 4,

Quartiere La Sguancia CH - 6912 Lugano Pazzallo, Switzerland

Full list of author information is available at the end of the article
}

leap about, eat, rest, digest, leap about again, and so from morn till night and from day to day, fettered to the moment and its pleasure or displeasure, and thus neither melancholy nor bored. This is a hard sight for a man to see; for, though he thinks himself better than the animals because he is human, he cannot help envying them their happiness - what they have, a life neither bored nor painful, is precisely what he wants, yet he cannot have it because he refuses to be like an animal'.

This powerful consideration by Nietzsche, taken from one of his most meaningful works On the Use and Abuse of History for Life [2], recalls that tragedy is the element that marks unequivocally our life in the world, together with memory that obsessively reminds man how his openness to things is characterised by a completeness and a happiness that, as Jankélévítch said, occurs in the world as lightning event [3].

In short, happiness appears to us as a transitory event, almost like a furtive gift of the gods, where pain seems to live in us as a usual condition. Man is an ill animal, 
as much as he is 'open to the meaning' as projects embodied in the world, and, at the same time, he is inevitably struck by pain and, above all, by death, that is the implosion of every meaning.

Memory, shifting from the extended to the identity level, takes the shape of 'nostalgia for the centre'; that is, the lost Unit (that is to say the Principle from which humans originate) that from a cultural point of view can be found in the history of religions and in general in the human thought [4-7]. The 'nostalgia for the Centre' is mainly an erotic archetype, a tormenting desire of love and beauty, of ontological integrity and harmony, increasingly fuelled by the melancholy that in Schelling's view is a "veil that falls on everything", things whose finitude make us worried, anxious.

The question of ontological pain and the precariousness of life 'here and now' is absolutely crucial, because the 'cosmic silence' makes us dismayed in the width of spaces, as well as 'the silence of the other makes us feel alone in the small universe of relations' [8]. So question on the structural melancholy, paradigmatic expression of ontological pain, shouldn't be negletted due to its radical nature. Infact, even if often remains in the background, nearly frozen, exorcised, (see Pascal's Divertissement), it can never be cancelled, otherwise the deep meaning of existence will be lost. In this context, memory, through language, that is to say culture, makes us understand to what extent depression (ontological or structural, human pain that embodies the ontic data; that is, to say, the single historical periods and single biographies) is a middle ground between the memory of the lost original Principle or Centre merely symbolic or religious, and the unquenchable aspiration for re-integration.

In conclusion, after this existential recognition and in the light of the biological considerations on depression herewith developed, we formulated a study hypothesis that can be expressed as follows: since the biochemical characteristics of the depressed population are the same as those of the population suffering from scleroderma, and since all people suffering from scleroderma are depressed, but not vice versa, is it rational to think that, close to a cultural origin of depression (the question on human structural and ontological precariousness herewith examined), there is a structural biological origin too? In other words, is it rational to think that depression may be the possible cause of more serious pathologies (for example, is inflammatory bowel disease, or osteoporosis, or neuroinflammation a cause or an effect of depression)?

\section{Depression and biological considerations}

Recently, from an experimental basis, the molecular depression hypothesis [9] and the involvement of interactome [10] have been formulated, as shown in Figures 1 and 2 .
It is well known that other assumptions about depressive disorder have exhaustively considered the platelet membrane as a bridge to psychiatric illness as a result of changes in viscosity [11]. When membrane viscosity is very low, due to the increase of arachidonic acid [12-14], the capacity of platelet and neuronal serotonin receptors to capture serotonin (5-hydroxytryptamine) [15] is impaired.

Since we know that serotonin does not cross the blood-brain barrier, the mechanism described could explain the strong similarity of the low concentration of serotonin neurons and platelets in depression [16-19]. In these circumstances, and in the absence of an efficient reuptake mechanism, some serotonin remains free in the brain neuronal domain, in the enteric neuron domain and in the circulation.

This can be a strong critical element in the relationship (direct and indirect) that a defect or an excess of serotonin (as in depression and other psychiatric disorders) can have with serious diseases such as scleroderma [20], bowel inflammation [21,22], multiple sclerosis [23], coronary heart disease [24], or osteoporosis [25], where a high incidence of depressive disorder is documented.

\section{Serotonin-bone connection}

Rosen [26], when discussing the connection between bone, brain and intestine, describes the serotonin cycle in a detailed and comprehensive way: two different types of enzymes, tryptophan hydroxylase (Tph) 1 and Tph2 promote the synthesis of serotonin in enterochromaffin cells and brain, respectively; serotonin released in the gut in part stimulates peristalsis and in part enters the bloodstream, is transported to platelets via the 5-hydroxytryptamine transporter (5HTT), and is stored or released during the process of coagulation.

In the central nervous system, serotonin, produced through the action of Tph2, is released at neuronal synapses. Its reuptake is controlled by the action of 5HTT. Since serotonin does not cross the blood-brain barrier, all its activity in the brain is mediated by phenomena of synthesis, reuptake and binding to $5 \mathrm{HTT}$ receptors.

This leads us to believe that the only changes in Tph2 or in 5HTT activity, by altering levels of serotonin in the brain, are the primary cause for the induction of osteoporotic disease [26]. This mechanism, moreover, would exclude the involvement of the platelets and their viscosity, as compared to the skeleton in its integration with brain and gut.

Analysis of Rosen [26] suggests that, as a result of lipoprotein receptor-related protein 5 (Lrp5) gene function loss, there are higher circulating levels of serotonin and that a deep modification of the 5HTT activity, adversely affects osteogenesis. 


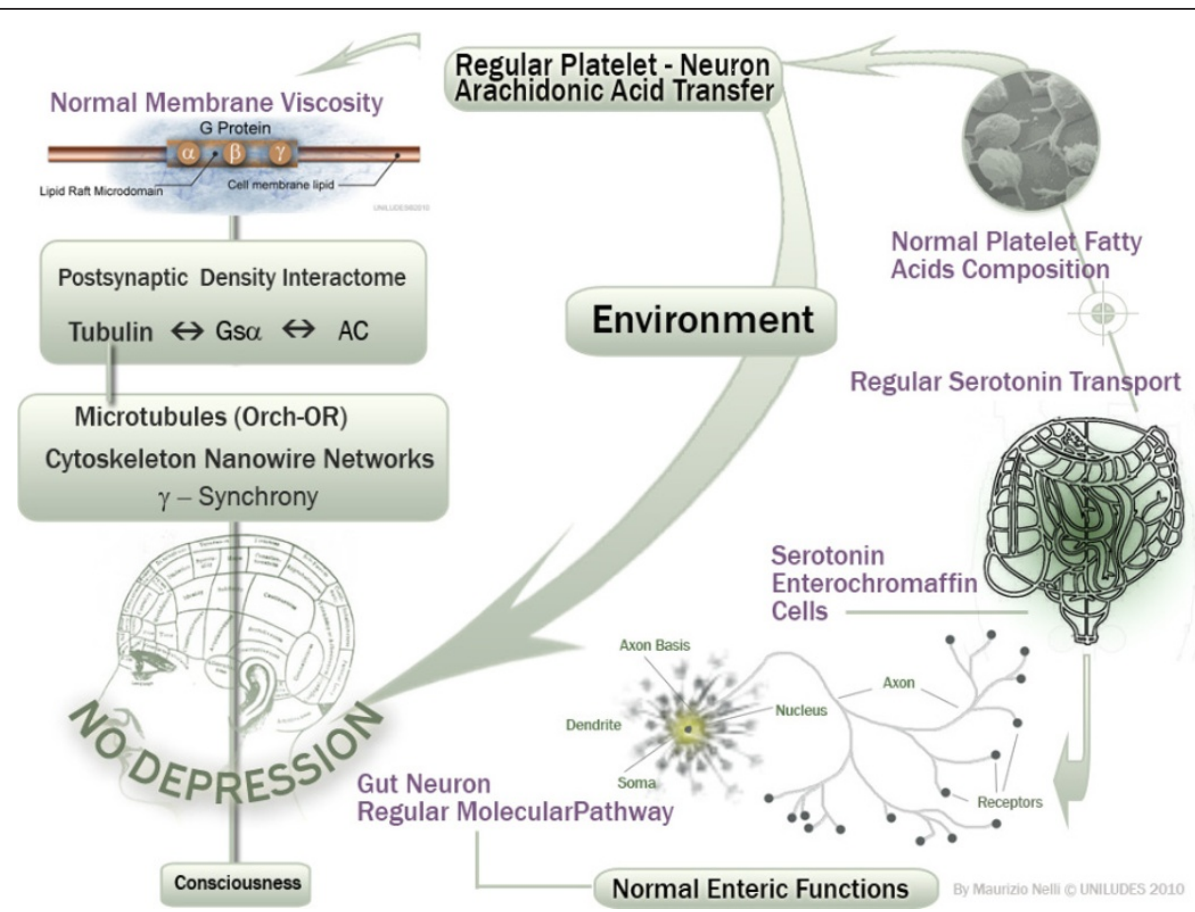

Figure 1 Schematic description of the serotonin pathway from enterochromaffin cells (ECs) to platelets and interactome regulation through the membrane viscosity (depending from the regular arachidonic acid transfer from platelets to brain and vice versa) under normal conditions.

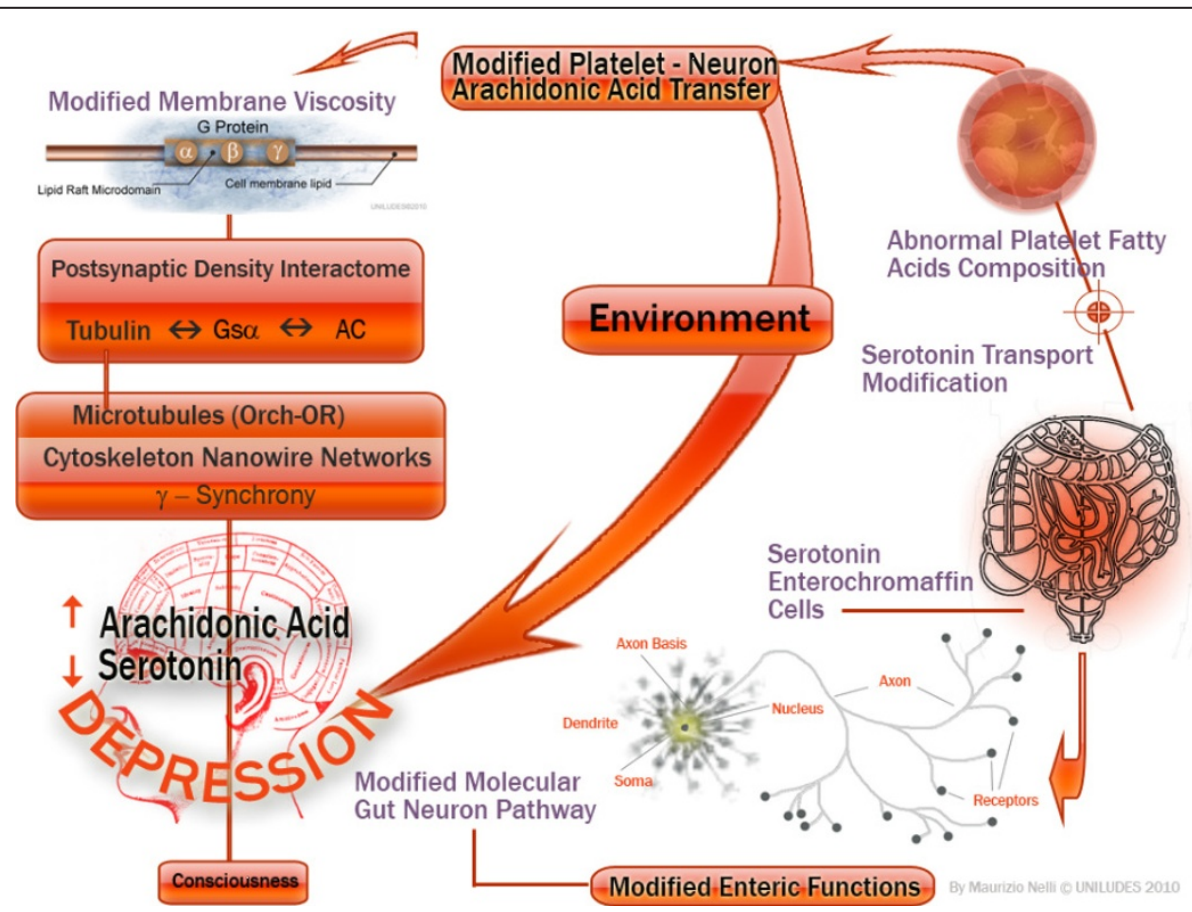

Figure 2 Schematic hypothesis, in conditions of platelet membrane fatty acid modifications, of the serotonin pathway, from enterochromaffin cells (ECs) to platelets, and regulation of the interactome through the membrane viscosity. When platelets reach a very high concentration of arachidonic acid, exchanges of arachidonic acid between platelets and the brain and vice versa are not possible; arachidonic acid increases in the brain and neurons, and platelet membranes become very fluid (loss of viscosity) impairing serotonin uptake in both cells. 
The results reported in the literature with regard to the involvement in osteoporosis of brain or intestinal serotonin, as well as its action on osteoclasts and osteoblasts, are conflicting. Rosen [26], citing Yadav's work [27], reports that intestinal serotonin inhibits bone formation independently from the activity of brain serotonin. In subsequent work, Yadav [28] reports that the influence of brain serotonin on bone mass takes precedence over that exerted by serotonin of intestinal origin. However, the same work emphasises how, according to the place of synthesis, serotonin regulates bone mass in different ways, inhibiting (duodenal serotonin) and favouring (brain serotonin) by attributing such effects to the serotonin condition of hormone or neurotransmitter.

The New England Journal of Medicine published a discussion about the article by Rosen [26]. Some authors disagree with Rosen's theory on the influence of serotonin, together with its origin and mode of transport, in the determination of the osteoporotic process.

Anderson et al. [29] stress the paradox that the increase in platelet serotonin in Lrp5 gene knockout rats and in subjects with osteoporosis pseudoglioma leads to bone loss, whereas treatment with selective serotonin reuptake inhibitors (SSRIs), which reduce platelet serotonin by about $80 \%$ to $95 \%$ is also responsible for the reduction of bone mass.

If serotonin apparently inhibits bone formation, it is puzzling that carcinoid syndrome is not commonly associated with osteoporosis.

de Jong et al. [30] emphasise that, after treatment with SSRIs, free serotonin should be high (it seems that the level of free serotonin after SSRI treatment is not known), making this condition similar to serotonin-producing subjects with metastatic carcinoid tumours, with the caveat that these subjects do not have any particular tendency to osteoporosis.

de Jong et al. [30] provide a possible explanation for the discrepancy, with regard to the metabolic clearance of serotonin.

Since SSRIs also reduce serotonin clearance in peripheral transporter-expressing target organs, such as bone, serotonin receptor activation is increased. In contrast, in patients with carcinoid tumours, transporter function is intact and metabolic clearance can be highly upregulated [31].

Rosen [32] makes observations stressing two main aspects of the mechanisms that cause the osteoporotic phenomenon. Firstly, with respect to the mechanism of bone loss from sympathetic activity, activated adrenergic receptors on osteoblasts suppress critical transcription factors necessary for bone formation but also enhance osteoclastogenesis, principally by upregulating the osteoclast differentiation factor receptor activator of nuclear factor $\kappa \mathrm{B}$ ligand (RANKL) [33]. This is not a diversion of osteoblasts to osteoclasts, as noted by Speth [34], but rather a dynamic process of coupling that involves two cell types originating from distinct progenitor cells. Secondly, the mechanism of bone loss induced by SSRIs. [27]. Hence, it is conceivable that there is a balance in bone turnover between the central blockade of serotonin reuptake and changes that may be associated with circulating serotonin and its release from platelets.

Karsenty [35] states that inhibition of the serotonin of intestinal origin is an effective solution in the treatment of osteoporosis, and Battaglino et al. [36] state that experimental data suggest that serotonin plays a key role in bone homeostasis through an effect on osteoclasts differentiation. Regardless, there is unanimity of views, from the same authors, on the role of SSRIs in the osteoporotic process.

\section{Depression and osteoporosis}

In this maze of conflicting evidences, on the basis of the strong probability that circulating serotonin can be invoked in osteoporosis and, further, for the possible liability of the SSRIs in the induction of the osteoporotic phenomenon, we consider the hypothesis that derives from research conducted on the relationship between membrane viscosity and serotonin plausible with regard to the possible role of osteoporosis in depression [10-15]. Awareness of a strong link between depression and osteoporosis [25] is growing, although a clear definition of the connection between the two diseases is not yet available.

On the basis of the research conducted on the role of platelets and their membrane fatty acids [37] it has been shown that the viscosity could be a focus of attention in order to allow a new interpretation of the serotonin receptor uptake $[11,12]$ and of the relationship between depression, osteoporosis, and other diseases in which serotonin is involved with respect to possible anomalies in cell (platelet and neuron) concentration (Figure 3).

The above reasons make plausible, from a different point of view, that the involvement of depressive disorders on the osteoporotic phenomenon, as if to mimic SSRIs activity in their phase of initial platelet receptors reuptake inhibition, can cause a significant reduction of serotonin (see Figures 1 and 2).

In the sequence of the molecular events that can lead to fluctuation in the viscosity of the platelet membrane, namely the phenomenon of exchange of arachidonic acid from platelets and brain and vice versa, we have shown that when platelets are saturated with arachidonic acid this exchange is no longer possible $[13,14]$ and the two areas of serotonin receptors (platelets and neurons) could have limitations of serotonin reuptake for the reduction of viscosity [15], freeing serotonin. 


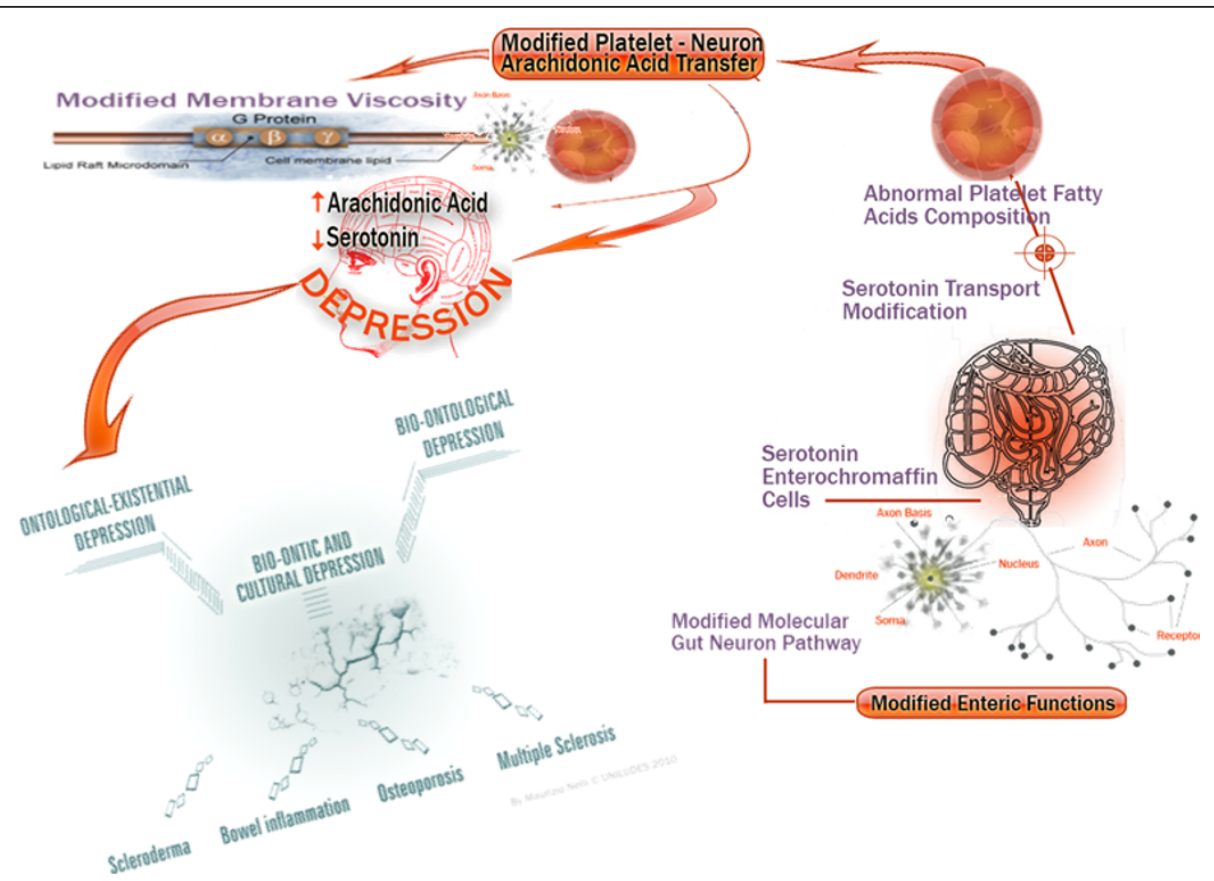

Figure 3 The possible links between depression and other pathologies where serotonin is involved, according to the hypothesis of compromised serotonin transport. The compromised serotonin transport, which depends on membrane viscosity, can cause conditions of increased or decreased serotonin uptake by platelets leading to altered platelet function that in turn could be involved in different pathologies.

An excess of serotonin, as suggested by Rosen and comparing the two theories, probably complementary, may lead to an insult to the bone.

The activity of SSRIs on the one hand, leads to a reduction of depressive disorder by promoting the entry of larger amounts of serotonin in the brain on the other hand, continuing the inhibiting effect of the serotonin uptake on the platelet membrane receptors [38]. This, essentially leaves the serotonin decoupled from platelet receptors and could maintain the osteoporotic effect. In short, even during depression treatment, platelet membrane viscosity does not change, and it would remain a permanent stimulus to the impairment of bone homeostasis and of other diseases that have serotonin inbalance as a common feature.

\section{Conclusions}

At the time it is shown that the viscosity of the platelet membrane is a general influencing factor for serotonin receptor uptake, a general principle governing the handling of serotonin itself is established with regard to its relations with the depressive disorder. It may also be involved, to a certain extent, in some pathologies that recognise serotonin changes; that is, scleroderma, inflammatory bowel disease, neuroinflammation, multiple sclerosis and osteoporosis.

The high incidence of depression, in these pathological conditions, leads us to consider a general phenomenological rule rather than a specific error in gene expression or loss of enzyme function. The viscosity of the membrane appears to be a concept more plausible than the fact that it is a phenomenon to which changes may contribute more general factors compared to the exclusivity of a gene expression error and/or an abnormality of enzyme function. The serotonin receptors and their subtypes, together with the modification of gene expression of transporters, represent a very complex and intriguing network. We must understand if it is possible to find a general and common rule to explain all the different molecular aspects of the serotonin pathways, tissue connections and responsibilities in its involvement in pathologies.

The platelet molecular error identified in depression $[9,11]$ seems to not be irreversible in all subjects, but could, in some cases, be partially recoverable by correction of membrane viscosity.

This refers to the portion of the population that may experience mood disorders of varying intensity where there is defective membrane dependent transport of serotonin, which could also affect correct osteblastogenesis.

The concept of membrane viscosity [11] and the implications that are reflected on the molecular homeostasis of the cytoskeleton, can be the link to which future research to better understand the complex phenomenon should be directed at, which bidirectionally links the brain-gut axis in relation to serotonin transport, and that likely makes the depressive condition the disorder to which other diseases may be related. 


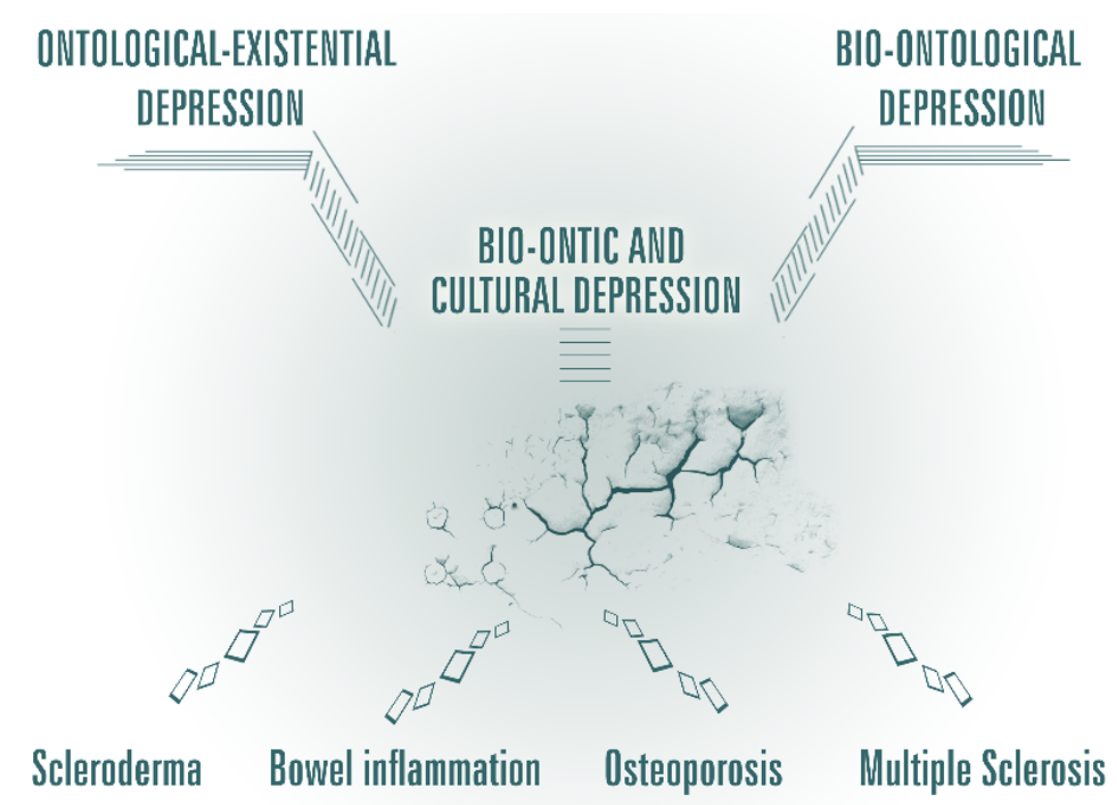

By Maurizio Nelli @ UNILUDES 2010

Figure 4 In our interpretative model, depression stands out as the primary cultural and biological structure of living (ontological version) with all its pathology classifying and historical-biographical relapses (ontic version).

In depression, the evidence of a reduced uptake of serotonin in platelets and neurons, justifies the possible influence of free serotonin on bone mass regardless of origin, brain or blood.

In conclusion, depression, is a logical correspondence between biological markers and biolocial-cultural expressions, considered as the essential interpretation key of human existence, from the biological point of view, as well as from a symbolic-cultural and existential perspective, according to Figure 4.

\footnotetext{
Author details

IInstitute 'Paolo Sotgiu' Quantitative and Evolutionary Psychiatry and Cardiology, L.U.De.S. University, Lugano, Switzerland, Via dei Faggi. 4, Quartiere La Sguancia CH - 6912 Lugano Pazzallo, Switzerland. 'Department of Medical Veterinary Sciences, University of Bologna, Bologna, Italy. ${ }^{3}$ Quantumbiolab, Department of Drug Sciences, University of Pavia, Viale Taramelli, 21, 27100 Pavia, Italy.
}

\section{Authors' contributions}

All the authors made substantial contributions to the design and concept of the study. All the authors were involved in drafting and revising the manuscript and have read and approved the final manuscript.

\section{Competing interests}

The authors declare that they have no competing interests.

Received: 8 October 2010 Accepted: 30 March 2011 Published: 30 March 2011

\section{References}

1. Thompson E, Rosch E: The Embodied Mind. Cognitive Science and Human Experience Cambridge, MA: MIT Press; 1991.
2. Nietzsche F: Untimely meditations, II, on the use and abuse of history for life. Cambridge, UK: Cambridge University Press; 1997.

3. Jankélévítch V: II non-so-che e il quasi niente Genova, Italy: Marietti; 1987.

4. Gabrielli F: L'uomo a due dimensioni. Anima e corpo, cura e salvezza dall'Orfismo al Platone pre-metafisico Lugano, Switzerland: Ludes University Press; 2009.

5. Leipoldt J, Schenke HM: Koptisch gnostiche Schriften aus dem PapyrusCodices von Nag Hammadi Bergstedt, Germany, H. Reich; 1960.

6. Lidzbarsky M: Ginza: Des Schatz oder das Grosse Buch der Mandder (Quellen der Religongeschichte, XIII/4). Göttingen-Leipzig, Germany; Vandenhoeck \& Ruprecht; 1925

7. Löwith K: Man between infinities. Measure. A Critical Journal Chicago, Henry Regnery Company; 1950, vol.1.

8. Carotenuto A: Le lacrime del male Milano, Italy: Bompiani; 2001.

9. Cocchi M, Tonello L, Rasenick MM: Human depression: a new approach in quantitative psychiatry. Ann Gen Psychiatry 2010, 9:25.

10. Cocchi M, Gabrielli F, Tonello L, Pregnolato M: Interactome hypothesis of depression. Neuroquantology 2010, 8:603-613.

11. Tonello $L$, Cocchi $M$ : The cell membrane: is it a bridge from psychiatry to quantum consciousness? Neuroquantology 2010, 8:54-60.

12. Cocchi $\mathrm{M}$, Tonello $\mathrm{L}$ : Biomolecular considerations in major depression and ischemic cardiovascular disease. Cent Nerv Syst Agents Med Chem 2010, 10:97-107.

13. Cocchi M, Tonello L, De Lucia A, Amato P: Platelet and brain fatty acids: a model for the classifcation of the animals? Part 1. Int J Anthropology 2009, 24:69-76.

14. Cocchi M, Tonello L, De Lucia A, Amato P: Platelet and brain fatty acids: a model for the classification of the animals? Part 2. Platelet and brain fatty acid transfer: hypothesis on arachidonic acid and its relationship to major depression. Int J Anthropology 2009, 24:69-76.

15. Heron DS, Shinitzky M, Hershkowitz M, Samuel D: Lipid fluidity markedly modulates the binding of serotonin to mouse brain membranes. Proc Natl Acad Sci USA 1980, 77:7463-7467.

16. Takahashi S: Reduction of blood platelet serotonin levels in manic and depressed patients. Folia Psychiatr Neurol Jpn 1976, 30:475-486.

17. Stahl SM: The human platelet. A diagnostic and research tool for the study of biogenic amines in psychiatric and neurologic disorders. Arch Gen Psychiatry 1977, 34:509-516. 
18. Kim HL, Plaisant O, Leboyer M, Gay C, Kamal L, Devynck MA, Meyer P: Reduction of platelet serotonin in major depression (endogenous depression) [in French]. C R Seances Acad Sci III 1982, 295:619-622.

19. Dreux C, Launay JM: Blood platelets: neuronal model in psychiatric disorders. Encephale 1985, 11:57-64.

20. Ostojic P, Zivojinovic S, Reza T, Milivojevic D, Damjanov N: Symptoms of depression and anxiety in Serbian patients with systemic sclerosis: impact of disease severity and socioeconomic factors. Mod Rheumatol 2010, 20:353-357.

21. Kurina $L$, Goldacre $M$, Yeates $D$, Gill $L$ : Depression and anxiety in people with inflammatory bowel disease. J Epidemiol Community Health 2001, 55:716-720

22. Graff $L A$, Walker $J R$, Bernstein $C N$ : Depression and anxiety in inflammatory bowel disease: a review of comorbidity and management. Inflamm Bowel Dis 2009, 15:1105-1118.

23. Horstman LL, Jy W, Ahn YS, Zivadinov R, Maghzi AH, Etemadifar M, Alexander JS, Minagar A: Role of platelets in neuroinflammation: a wideangle perspective. I Neuroinflammation 2010, 7:10

24. Cocchi M, Tonello L, Lercker G: Fatty acids, membrane viscosity, serotonin and ischemic heart disease. Lipids Health Dis 2010, 9:97.

25. Bab IA, Yirmiya R: Depression and bone mass. Ann NY Acad Sci 2010, 1192:170-175.

26. Rosen CJ: Serotonin rising - the bone, brain, bowel connection. $N$ Engl $J$ Med 2009, 360:957-959.

27. Yadav VK, Ryu JH, Suda N, Tanaka K, Gingrich JA, Schütz G, Glorieux FH, Chiang CY, Zajac JD, Insogna KL, Mann JJ, Hen R, Ducy P, Karsenty G: Lrp5 controls bone formation by inhibiting serotonin synthesis in the duodenum. Cell 2008, 135:825-837.

28. Yadav VK, Oury F, Suda N, Liu ZW, Gao XB, Confavreux C, Klemenhagen KC, Tanaka KF, Gingrich JA, Guo XE, Tecott LH, Mann JJ, Hen R, Horvath TL, Karsenty G: A serotonin-dependent mechanism explains the leptin regulation of bone mass, appetite, and energy expenditure. Cell 2009, 138:976-989.

29. Anderson GM, Cook EH Jr, Blakely RD: Serotonin rising. N Engl J Med 2009, 360(24):2580.

30. de Jong WHA, de Vries EGE, Kema IP: Serotonin rising. N Engl J Med 2009, 360(24):2580-1.

31. Gillis CN: Peripheral metabolism of serotonin. In Serotonin and the cardiovascular system. Edited by: Vanhoutte PM. New York: Raven Press; 1985:27-36.

32. Rosen CJ: Serotonin rising. N Engl J Med 2009, 360(24):2581-2.

33. Elefteriou F, Ahn JD, Takeda S, Starbuck M, Yang X, Liu X, Kondo H, Richards WG, Bannon TW, Noda M, Clement K, Vaisse C, Karsenty G: Leptin regulation of bone resorption by the sympathetic nervous system and CART. Nature 2005, 434:514-520.

34. Speth RC: Serotonin rising. N Engl J Med 2009, 360(24):2581.

35. Karsenty G: Regulation of bone mass by serotonin: molecular biology and therapeutic implications. Annu Rev Med 2011, 62:27.1-27.9

36. Battaglino R, Fu J, Späte U, Ersoy U, Joe M, Sedaghat L, Stashenko P: Serotonin regulates osteoclast differentiation through its transporter. J Bone Mineral Res 2004, 19:1420-1430.

37. Cocchi M, Tonello L, Tsaluchidu S, Puri BK: The use of artificial neural networks to study fatty acids in neuropsychiatric disorders. BMC Psychiatry 2008, 8(Suppl. 1):S3.

38. Axelson DA, Perel JM, Birmaher B, Rudolph G, Nuss S, Yurasits L, Bridge J, Brent DA: Platelet serotonin reuptake inhibition and response to SSRIs in depressed adolescents. Am J Psychiatry 2005, 162:802-804.

doi:10.1186/1744-859X-10-9

Cite this article as: Cocchi et al: Depression, osteoporosis, serotonin and cell membrane viscosity between biology and philosophical anthropology. Annals of General Psychiatry 2011 10:9.

\section{Submit your next manuscript to BioMed Central and take full advantage of:}

- Convenient online submission

- Thorough peer review

- No space constraints or color figure charges

- Immediate publication on acceptance

- Inclusion in PubMed, CAS, Scopus and Google Scholar

- Research which is freely available for redistribution

Submit your manuscript at www.biomedcentral.com/submit
Biomed Central 